\title{
CLC (CENTERED LEARNING CIRCULAR): METODE REVITALISASI KEILMUAN EKONOMI ISLAM UNTUK KALANGAN MAHASISWA
}

\author{
Nur Fitroh Febrianto*, Wahyuningsari \\ Universitas Negeri Surabaya
}

\begin{abstract}
As the development of information and increasingly sophisticated technology this global era, not least the young generation, especially students who fall into the hedonism culture. Behavior hedonism related to squeezing economic life, so that the Indonesian people, especially students understand very well be an economic system that is set in the religion of the Islamic Economic system, need for us to understanding the implementation of religion in the economic field intensively. Improvements of social and economic poblem can be resolved through solutions offered by the Al-Quran and Al-Hadith. Laws and guidelines are clearly contained there in, but how the application of a person against the Islamic economic principles will depend in how they understand the rules. Therefore CLC emerge from the output of the Qur'an and Al-Hadith as the solution to social problems. Circular discussion-based learning with studying the phenomenon of the contemporary economy is expected to accelerate the economic understanding of Islam among non-economic students of Islam. CLC can also be interpreted mentoring. The method used is the analysis of FGD and fusion methods of comparative literature. The research results can be obtained, that turned out to be an average of CLC is a method of supporting the economic understanding of Islam for the students who are accelerated out of the classroom. Thus CLC (Centered Learning Circular) is a scientific method of economic revitalization of Islam for the students.
\end{abstract}

Keywords : CLC, Revitalization, Economic

\begin{abstract}
Abstrak
Perilaku hedonisme erat kaitannya dengan ketimang tindihan kehidupan ekonomi, maka agar masyarakat Indonesia khususnya mahasiswa paham betul akan sebuah sistem ekonomi yang diatur dalam agama yakni sistem Ekonomi Islam, perlunya pemahaman implementasi agama dalam bidang ekonomi secara intensif. Perbaikan-perbaikan dari poblematika sosial dan ekonomi dapat dituntaskan melalui solusi yang ditawarkan oleh Al-Qur'an dan Al-Hadits. Hukum dan pedoman secara jelas terkandung didalamnya, namun bagaimana penerapan seseorang terhadap kaidah ekonomi Islam tersebut tentu bergantung bagaimana cara mereka memahami kaidah. Oleh karena itulah CLC muncul dari output Al-Qur'an dan Al-Hadits sebagai solusi untuk mengatasi problematika sosial. Pembelajaran berbasis diskusi melingkar dengan mengkaji fenomena ekonomi kontemporer ini di harapkan dapat mempercepat pemahaman ekonomi Islam dikalangan mahasiswa non ekonomi islam. CLC dapat juga diartikan mentoring. Metode penelitian yang digunakan adalah analisis FGD dan metode fusi-komparatif dari studi pustaka. Hasil penelitian tersebut dapat diperoleh, bahwa ternyata rata-rata CLC ini merupakan metode penunjang pemahaman ekonomi Islam bagi kalangan mahasiswa yang bersifat akselerasi di luar kelas. Dengan demikian CLC (Centered Learning Circular) adalah sebuah metode revitalisasi keilmuan ekonomi Islam untuk kalangan mahasiswa.
\end{abstract}

Kata kunci: CLC, Revitalisasi, Ekonomi

Received: 25 Desember 2016; Accepted: 13 Januari 2017; Published: 21 Januari 2017

*Korespondensi: Program Studi Ekonomi Islam, Fakultas Ekonomi, Universitas Negeri Surabaya.

Jl. Ketintang Surabaya 60231. Email: Nurfitroh70@gmail.com. 


\section{PENDAHULUAN}

Perkembangan arus globalisasi yang semakin meningkat membuat seseorang akan paham betul berbagai permasalahan yang ada di dunia. Baik itu masalah politik, hukum, sosial, budaya, serta ekonomi. Ekonomi memiliki peranan penting bagi pembangunan sebuah negara. Hal ini bisa dibuktikan, ketika sebuah negara dikatakan maju, maka akan ditanya total pendapatan perkapita atau GDPnya. Begitupun sebaliknya, ketika sebuah negara itu dikatakan negara miskin, maka akan ditanya GDPnya pula. Akhir-akhir ini berita mengenai permasalahan ekonomi begitu ramai diperbincangkan. Mulai dari lemahnya nilai tukar rupiah terhadap dollar, timpangnya neraca perdagangan Indonesia, hingga turunnya perekonomian China yang akan berpengaruh terhadap perekonomian Indonesia.

Ekonomi Islam mempunyai peranan penting untuk menjawab tantangantantangan ekonomi. Hal ini dikarenakan, Ekonomi Islam ada karena Al-Qur'an, Al-Hadits, dan Ijtihad Para 'Ulama sehingga sudah terjamin isi-isinya untuk menyelesaikan berbagai pertanyaan dari permasalahan ekonomi konvensional. Hal ini bisa dilihat dari grafik perkembangan industri jasa keuangan syariah di Indonesia pada tahun 2010 hingga 2014.

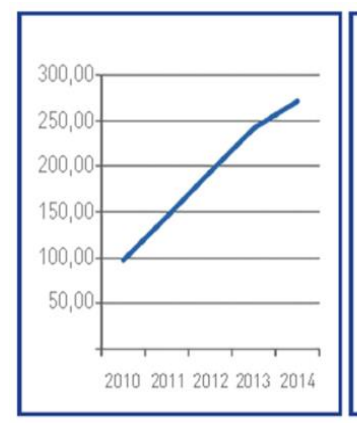

Perbankan Syariah

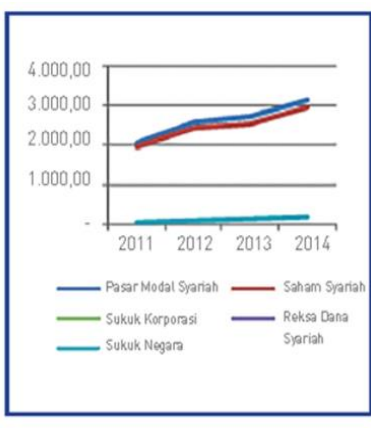

Pasar Modal Syariah

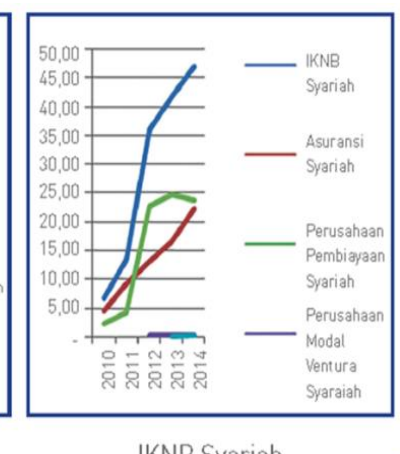

IKNB Syariah

Gambar 1 : Grafik Perkembangan Industri Jasa Keuangan Syariah Sumber Data: Buku Road Map OJK IKNB SYARIAH 2015-2019

Dari grafik di atas, bisa dilihat bahwa dari tahun ke tahun, angka perkembangan ekonomi syariah setiap tahunnya mengalami peningkatan. Baik itu perbankan syariah, pasar modal syariah, dan IKNB Syariah. Tercatat pada tahun 2014, perbankan syariah di Indonesia lebih dari 250. Untuk pasar modal, tahun 2014 lebih dari 3.000 dan IKNB syariah lebih dari 45. Hal ini membuktikan bahwa ekonomi Islam mampu sebagai solusi dari permasalahan perekonomian. 
Akan tetapi, perkembangan industri keuangan syariah di Indonesia tidak diimbangi dengan pemahaman akan keuangan syariah itu sendiri. Hal ini dapat dilihat dari road map IKNB Syariah dari OJK (Otoritas Jasa Keuangan).

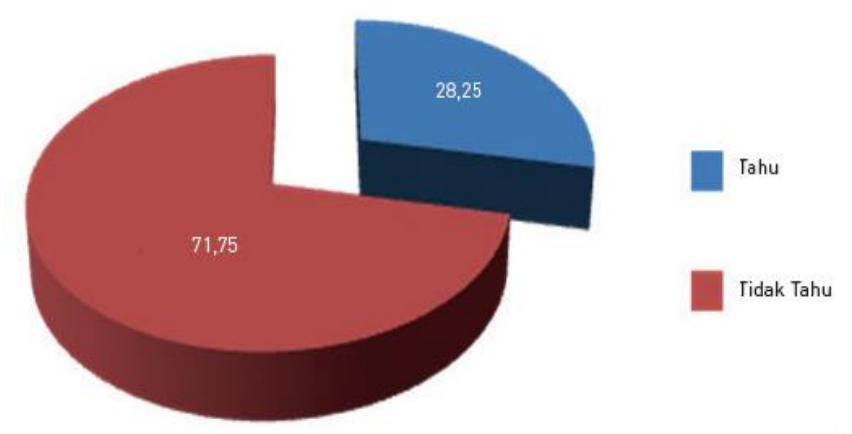

Gambar 2 : Grafik Pemahaman Keuangan Syariah Buku Road Map OJK IKNB SYARIAH 2015-2019

Oleh karena itu, dibutuhkan sebuah metode pembelajaran yang menarik. Agar masyarakat Indonesia khususnya mahasiswa paham betul akan sebuah sistem Ekonomi Islam, terlebih lagi ketika dapat mengimplementasikan di tengah masyarakat. Salah satunya melalui metode yang telah di inovasikan penulis yakni CLC (Centered Learning Circular). CLC merupakan salah satu inovasi metode pembelajaran efektif untuk mengenalkan ekonomi Islam kepada mahasiswa. Hal ini dikarenakan motode dua arah yaitu dari pengajar kepada penerima ilmu, membuat suasana belajar semakin kondusif dan aktif.

Ditinjau dari segi bahasa Dakwah berarti: panggilan, seruan, atau ajakan. Dalam pengertian istilah oleh Toha Yahya Oemar menyatakan dakwah adalah upaya mengajak umat dengan cara bijaksana kepada jalan yang benar sesuai dengan perintah Tuhan untuk kemaslahatan dunia dan akhirat. Orang yang berdakwah biasa disebut dengan $D a{ }^{\prime} i$ dan orang yang menerima dakwah disebut dengan Mad'u. Berdasarkan pengertian diatas dapat disimpulkan bahwa dakwah adalah suatu proses menjadikan perilaku muslim yang harus diadakan kepada seluruh manusia, dimana didalamnya terdapat unsur: $d a{ }^{\prime} i$ (subjek), maaddah (materi), thoriqoh (metode), washilah (media), dan mad'u (objek) dalam 
mencapai maqashid (tujuan) dakwah yang melekat dengan tujuan islam yaitu mencapai kebahagiaan hidup di dunia dan di akhirat. ${ }^{1}$

Pola dakwah dibagi menjadi tiga secara umum, yakni Dakwah Kultural, Dakwah Politik, Dakwah Ekonomi. Dalam hal ini penulis lebih fokus pada dakwah ekonomi. Dakwah ekonomi adalah aktifitas dakwah umat Islam yang berusaha mengimplementasikan ajaran Islam yang berhubungan dengan prosesproses ekonomi guna peningkatan kesejahteraan umat. Dakwah ekonomi berupaya untuk meningkatkan kesejahteraan umat Islam melalui implementasi ajaran Islam. Diantara ajaran Islam yang memiliki relevansi dengan dakwah ekonomi ada pada aspek produksinya, distribusi, supplier, pemanfaatan barang dan jasa. Dengan penerapan dakwah ekonomi diharapkan meningkat pula kesejahteraan umat Islam.

Dakwah adalah sebuah proses, karena dakwah bukan kegiatan sekali pakai yang kemudian berhasil mencapai tujuan. Dengan demikian berjalannya suatu proses sangat terkait dengan metode atau cara proses tersebut dijalankan. Metode dakwah secara umum ada tiga berdasakan surat An-Nahl: 125 yaitu: Metode Bil Hikmah, Metode Mai'idzoh Hasanah dan Metode Mujadalah. CLC merupakan sebuah istilah singkat dari Centered Learning Circular yang berarti pembelajaran melingkar terpusat mengandung makna penyampaian nilai yang mengandung kebaikan secara melingkar bersamaan dan terpusat pada seorang pembicara. Kemudian kajian bersama mengenai fenomena dan implementasi dari nilai yang disampaikan, dalam hal ini adalah ekonomi islam secara bersamaan. Metode ini adalah bentuk pembelajaran dakwah terkonsep. Dalam budaya terdahulu dapat disebut Liqo' atau Halaqoh.

Secara bahasa halaqah artinya lingkaran dan liqo` artinya pertemuan. Secara istilah halaqah berarti pengajian dimana orang-orang yang ikut dalam pengajian itu duduk melingkar. Dalam bahasa lain bisa juga disebut majelis taklim, atau forum yang bersifat ilmiah. Hanya jika kajian di era terdahulu adalah kajian agama yang kondisional atau belum terarah dalam satu keilmuan, CLC mengkhususkan pada keilmuan ekonomi islam dan berguna sebagai proses akselerasi pemahaman mahasiswa. 


\section{METODE PENELITIAN}

Penulisan ini menggunakan metode analisis FGD dan metode fusi-komparatif dari studi pustaka. Analisis FGD yang ditujukan untuk menggali informasi, kesepakatan, dan persamaan persepsi pada tingkat masyarakat atau komunitas. Dalam hal ini kami lakukan dengan para praktisi ekonomi islam seperti pengajar dan para ulama terkait di lingkungan prodi Ekonomi Islam Universitas Negeri Surabaya. Melalui FGD beberapa permasalahan yang dihadapi oleh masyarakat dapat diungkapkan secara bersama-sama dan juga diambil kesepakatan mengenai suatu hal.

Metode kedua fusi komparatif dari studi pustaka berperan sebagai pembanding beberapa literatur dari berbagai sumber, sehingga memperoleh inovasi sebagai penggabungan beberapa analisis data. Metode ini bersifat abstraksi karena dilakukan tanpa melalui tahap eksperimental. Berbagai kajian dan sumber literatur didapati analisis yang kemudian diperbandingkan dan digabungkan sehingga menghasilkan kesatuan yang utuh berupa karya tulis ilmiah ini. Meskipun tanpa eksperimental langsung, karena didapati dari analisis serta kajian dari berbagai jurnal dan buku, maka dapat diketahui konsepsi ini mampu diterapkan pada saat percobaan langsung.

\section{HASIL DAN PEMBAHASAN}

\section{Metode CLC sebagai Revitalisasi Keilmuan Ekonomi Islam untuk Kalangan}

\section{Mahasiswa}

Metode CLC sebagai revitalisasi keilmuan ekonomi Islam memiliki konsep yang tentunya sejalan dengan indikator tolok ukur keberhasilan CLC itu sendiri. Upaya untuk mensukseskan CLC tersebut tidak cukup hanya didekati melalui ajakan satu pihak, melaikan memerlukan pendekatan lain dengan melihat keseluruhan potensi yang ada. Hal tersebut dapat dilihat dari konsep dan ketentuan dari tenaga pendidik atau murobbi, peserta didik, sarana dan prasarana, serta kurikulum dari CLC itu sendiri. 


\section{Tenaga Pendidik}

Islam sangat mengahargai dan menghormati orang-orang yang berilmu pengetahuan dan bertugas sebagai pendidik. Sebagaimana Allah berfirman dalam surah Al-Mujadilah ayat 11:

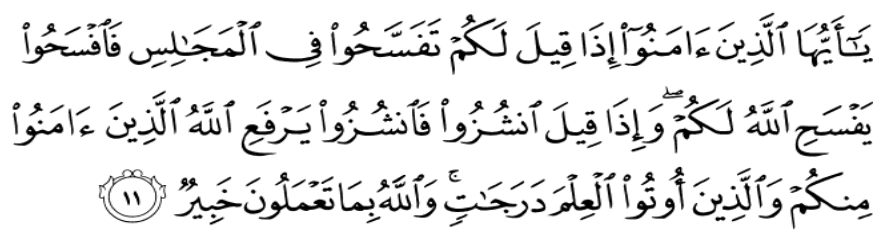

Artinya :

"Hai orang-orang beriman apabila dikatakan kepadamu: "Berlapang-lapanglah dalam majlis", maka lapangkanlah niscaya Allah akan memberi kelapangan untukmu. Dan apabila dikatakan: "Berdirilah kamu", maka berdirilah, niscaya Allah akan meninggikan orang-orang yang beriman di antaramu dan orangorang yang diberi ilmu pengetahuan beberapa derajat. Dan Allah Maha Mengetahui apa yang kamu kerjakan.'

Sehinga dari sinilah pendidik memiliki beberapa fungsi, diantaranya: a. fungsi penyucian, artinya sebagai pemelihara diri, pengembang, serta pemelihara fitrah manusia; b. fungsi pengajaran, artinya sebagai penyampai ilmu pengetahuan dan berbagai keyakinan kepada manusia agar mereka menerapkan seluruh pengetahuannya dalam kehidupan sehari-hari, maka itulah sebabnya Islam sangat menghargai dan menghormati orang-orang yang berilmu pengetahuan dan bertugas sebagai pendidik yang mempunyai tugas yang sangat mulia .

\section{Syarat-Syarat Pendidik atau Murobbi}

Dalam proses pembelajaran dengan menggunakan metode CLC, tenaga pendidik diharuskan untuk mengenal lingkungan dan kepribadian peserta didiknya. Hal ini dikarenakan Murobbi memiliki tanggung jawab memberikan bimbingan kepada peserta didik dalam perkembangan jasmani dan ruhaninya agar dapat lebih optimal dalam menyampai isi kandungan yang disampaikan, khususnya ekonomi Islam.

Menurut Tim Penyusun Buku Teks Ilmu Pendidikan Islam Perguruan Tinggi Agama/ IAIN, syarat yang harus dipenuhi oleh seseorang yang ingin 
menjadi pendidik ialah bertakwa kepada Allah, berilmu, sehat jasmaniah, baik akhlaknya, bertanggung jawab, dan berjiwa nasional ${ }^{5}$. Sementara kriteria akhlak yang dituntut, antara lain a. mencintai jabatannya sebagai pendidik; b. bersikap adil pada muridnya; c. harus gembira dan berwibawa; d. berlaku sabar dan tenang; e. harus bersifat manusiawi; f. bekerjasama dengan pendidik lainnya; g. bekerjasama dengan masyarakat.

Menurut pendapat lain, pendidik harus memenuhi syarat-syarat agar usahanya mendidik dapat berhasil, yaitu a. mengerti ilmu mendidik sebaikbaiknya, sehingga segala tindakannya dalam mendidik itu disesuaikan dengan jiwa peserta didiknya; b. memiliki bahasa yang begitu baik dan menggunakannya sebaik-baik mungkin sehingga dengan bahasa itu peserta didik tertarik kepada pelajarannya; c. mencintai peserta didiknya. Sebab, cinta senantiasa mengandung arti menghilangkan kepentingan diri sendiri untuk keperluan orang lain.

Sehingga dapat disimpulkan, bahwa seorang pendidik harus menguasai ilmu pengetahuan khususnya ekonomi Islam yang akan diajarkan kepada pesera didiknya, serta sikap terbuka dan sabar dalam mengajar merupaka syarat wajib yang harus dimiliki oleh Murobbi.

\section{Sarana dan Prasarana}

Salah satu faktor pendukung dari keberhasilan CLC salah satunya ditentukan dari sarana dan prasarana. Walaupun bukan faktor utama keberhasilan penerapan metode tersebut, akan tetapi sarana dan prasarana memiliki bagian penting dalam proses belajar-mengajar.

Bentuk prasarana dalam pendidikan tersebut berupa benda atau barang, seperti tanah, bangunan sekolah, jalan, dan transportasi yang menghubungkan masyarakat dengan sekolah, lapangan olahraga, dan sebagainya.

Akan tetapi, sarana dan prasarana yang dibutuhkan untuk menggunakan metode CLC ini sangatlah sederhana. Hal ini dikarenakan konsep metode pembelajaran CLC hampir sama dengan konsep pembelajaran Outing School yaitu pembelajaran diluar kelas. Salah satu bentuk sarana dan prasarana tersebut yaitu: 
a. Tempat Nyaman dan Suci

Pembelajaran akan efektif apabila tempat yang digunakan nyaman dan suci. Hal ini juga berkaitan dengan adab-adab untuk mengkaji ayat-ayat AlQur'an yang salah satu adabnya yaitu penggunaan tempat yang suci. Hal ini sesuai dengan firman Allah ayat Al-Baqarah ayat 222:

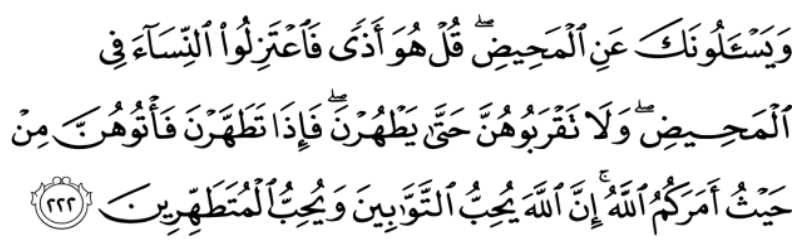

Yang artinya:

"Mereka bertanya kepadamu tentang haidh. Katakanlah: "Haidh itu adalah suatu kotoran". Oleh sebab itu hendaklah kamu menjauhkan diri dari wanita di waktu haidh; dan janganlah kamu mendekati mereka, sebelum mereka suci. Apabila mereka telah suci, maka campurilah mereka itu di tempat yang diperintahkan Allah kepadamu. Sesungguhnya Allah menyukai orang-orang yang bertaubat dan menyukai orang-orang yang mensucikan diri”.

b. Alat/media Pembelajaran

Pembelajaran dengan metode CLC, dapat menggunakan alat/media Microsoft Powerpoint. Hal ini karena dapat memahamkan peserta didik melalui visualisasi. Penggunaan buku maupun literatur apapun juga dapat menunjang keberhasilan penggunaan pembelajaran dengan metode CLC.

\section{Peserta Didik}

Peserta didik dalam pendidikan Islam adalah anak yang sedang tumbuh dan berkembang, baik secara fisik, maupun psikologis untuk mencapai tujuan pendidikannya melalui lembaga pendidikan ${ }^{9}$, Sedangkan peserta didik adalah orang-orang yang sedang memerlukan pengetahuan atau ilmu, bimbingan, maupun arahan dari orang lain.

a. Adab Peserta Didik dalam Islam

Adab peserta didik dalam proses pembelajaran dengan metode CLC sangatlah dibutuhkan. Hal ini dikarenakan sebagai seorang yang ingin 
mendapat didikan maka seharusnya menempatkan sikap dan sifat yang sesuai dengan situasi dan kondisi sebagai peserta didik.

Ada empat akhlak yang harus dimiliki oleh peserta didik, yaitu (1) seorang peserta didik harus membersihkan hatinya dari kotoran dan penyakit hati sebelum ia menuntut ilmu, karena belajar merupakan ibadah; (2) seorang peserta didik harus mempunyai tujuan menuntut ilmu dalam kerangka menghiasi jiwa dengan sifat keutamaan, mendekatkan diri kepada Allah SWT, bukan untuk kemegahan dan kedudukan; (3) seorang peserta didik harus tabah dalam memperoleh ilmu pengetahuan dan bersedia merantau; (4) seorang didik wajib menghormati pendidiknya dan berusaha memperoleh kerelaan dari pendidiknya

b. Konsep Pengelompokan

Metode pembelajaran CLC lebih menekankan terhadap pembelajaran efektif yang artinya bagaimana cara peserta didik dapat memahami materi ekonomi Islam secara sempurna. Oleh karena itu, CLC menerapkan metode pengelompokan yang satu kelompok terdiri dari lima hingga sepuluh anggota yang membentuk lingkaran (halaqoh) serta masing-masing anggota terdapat satu Murobbi atau pendidik. Dengan demikian peserta didik yang merasa malu bertanya ketika didalam kelas akan lebih berani untuk bertanya seputar apa yang disampaikan oleh murobbi.

\section{Kurikulum CLC}

Kurikulum CLC telah tertanam dalam silabus pembelajaran setiap pertemuan. Terdapat tiga tahapan dalam pembelajaran CLC tersebut. Mulai dari tahap awal yaitu Basic atau dasar hingga tahap lanjutan atau advanced.

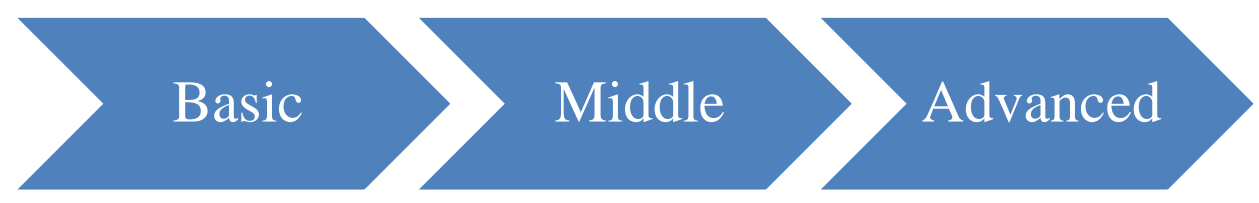


Setiap tahapan memiliki beberapa pertemuan dan materi yang berbeda-beda sesuai dengan ilmu yang akan diperoleh. Basic adalah sebuah tahapan dasar, dimana pemahaman ekonomi islam masih pada konsep-konsep sederhana dan dalil-dalil ringan, pada tahapan ini nilai yang ditanamkan adalah sebuah nilai baik yang sebaiknya dipegang teguh. Ketika telah menyelesaikan pertemuan pada tahapan basic, maka diperbolehkan melanjutkan kepada tahapan Middle atau pertengahan. Pada tahapan middle, pemahaman bukan lagi soal mengetahui konsep ekonomi islam, tetapi lebih pada pengamatan dan komparasi antara ekonomi islam dan fenomena konvensional dari prinsip hingga praktiknya di lingkungan. Tahapan ini menjadi sebuah tahapan observasi dan tahap menuju tingkatan lanjut yakni Advance. Tingkat lanjut adalah tingkat kematangan prinsip dan problem solving terhadap fenomena ekonomi. ketiga tahapan ini dilakukan secara berkesinambungan dan dalam waktu yang terkonsep dalam silabus. Sehingga menjadi sarana akselerasi pemahamana ekonomi islam mahasiswa ekonomi islam maupun non ekonomi islam. Akan tetapi setelah menyelesaikan pada tahapan Advanced atau lanjutan, maka dianjurkan untuk mengimplementasikan ilmu ekonomi Islam yang telah didapat dengan cara mengajar pada tahapan dibawahnya ataupun dapat mengimplementasikan dalam kehidupan sehari-hari, baik dalam dunia bisnis mapun yang lainnya. Dalam setiap tahapannya proses pembelajaran CLC sebagai metode revitalisasi keilmuan ekonomi Islam terus berjalan dengan efektif.

Adanya CLC di kampus sebagai sebuah metode penunjang pembelajaran ekonomi islam merupakan tirai pembuka sekat dimana ekonomi islam hanya berlaku bagi kaum sarungan dan santri. Ekonomi islam adalah nilai yang universal dan implementif untuk menyelesaikan permasalahan ekonomi. Tuntutan perbaikan ekonomi yang cepat akan segera tertolong dengan metode ini, pembelajaran yang biasanya berlaku empat tahun setara strata satu dapat di percepat pemahamannya melalui metode ini. Perubahan paradigma inilah yang dimaksud merevitalisasi keilmuan. 


\section{PENUTUP}

Penerapan CLC adalah pembelajaran diluar kelas secara informal, namun pembelajarannya terkonsep dalam silabus dan terarah oleh sebuah kurikulum. Peserta terbuka umum, bukan hanya bagi mahasiswa jurusan ekonomi islam namun juga jurusan lain. Dengan pola diskusi CLC menjadi metode tarbiyah sekaligus dakwah yang tepat untuk kalangan mahasiswa. Hal ini dikarenakan metode tersebut sesuai dengan keadaan dan realita sosial dikalangan pemuda saat ini. Kesuksesaan dari penerapan CLC dikampus adalah terbentuknya karakter mahasiswa yang sesuai dengan Islam yaitu berakhlak, inovatif, kreatif, dan berwawasan global. Secara real, kesuksesaan yang tertinggi dari penerapan CLC ini yaitu ketika mahasiwa satu dengan yang lainnya saling mengajak dan mengenalakan atau mempromosikan kepada mahasiswa lainnya karena tujuan CLC ini lebih universal. Artinya implementasi didalam kehidupan sehari- hari dari apa saja yang didapatkan dari seorang tentor ataupun guru merupakan kesuksesan dari metode CLC ini. Dari implementasi tersebut, memungkinkan orang lain untuk mencoba mengikuti apa yang dilakukan oleh sesorang yang mengikuti CLC. Sehingga dari sinilah CLC (Centered Learning Circular) sebagai metode revitalisasi keilmuan ekonomi Islam untuk kalangan mahasiswa.

\section{DAFTAR PUSTAKA}

Ahmad Warson Munawir. 1997. Kamus al-Munawwir. Surabaya: Pustaka Progresif.

Pengertian Liqo diakses dari http://ukmagama.weebly.com/liqo-akhwat.html pada 18 April 2016

Salim, Haitami, dan Syamsul Kurniawan. 2012. Studi Ilmu Pendidikan Islam. Yogjakarta: AR-RUZZ MEDIA.

Basuki dan M. Miftahul Ulum. 2007. Pengantar Ilmu Pendidikan Islam. Ponorogo: STAIN Ponorogo Press.

Tim Walisongo Research Institute (WRI). 2001. "Media Pembelajaran” Dalam Materi Inservice Training KKG-MGMP. Semarang: WRI.

Ihsan, Hamdani dan Fuad Ihsan. 1998. Filsafat Pendidikan Islam. Bandung: Pustaka Setia.

Arifim, HM. 1976. Hubungan Timbal Balik Pendidikan Agama: Di Lingkungan Sekolah dan Keluarga. Jakarta: Bulan Bintang. 
Mudyahardjo, Redya. 2001. Pengantar Pendidikan Sebuah Studi Awal tentang dasar-dasar Pendidikan pada Umumnya dan Pendidikan di Indonesia. Jakarta: Raja Grafindo Persada.

Muhaimin dan Abdul Mujib. 1993. Pemikiran Pendidikan Islam, Kajian Filosofi dan Kerangka Dasar Operasionalisasinya. Bandung: Trigenda karya.

Fahmi, Asma Hasan. 1974. Sejarah dan Filsafat Pendidikan Islam. Jakarta: Bulan Bintang. 